\title{
The Disastrous Flash Flood of Mandra in Attica-Greece and now What?
}

\author{
Anastasios I Stamou* \\ Department of Water Resources and Environmental Engineering, School of Civil Engineering, National Technical University of Athens, Greece
}

Submission: June 11, 2018; Published: July 13, 2018

*Corresponding author: Anastasios I Stamou, Department of Water Resources and Environmental Engineering, School of Civil Engineering, National Technical University of Athens, Greece, Tel: +30 210772 2809; Fax: +30 210772 2814, Email: stamou@central.ntua.gr

\begin{abstract}
The technical aspects of the disastrous flash flood in the town of Mandra in Attica, Greece on the 15th of November 2017 that caused 23 deaths are critically described. The disaster was caused as a result of (i) the extremely small cross-sectional areas of the two main streams of Mandra due to various private and public constructions, and (ii) the inadequacy of the storm protection works. The flood wave, which was triggered by the extreme rainfall of a return period higher than 150-200 years, passed via the main roads of the town causing disastrous impacts that could have been reduced, if there was an Early Warning System (EWS) that could have activated a preparedness plan. The main actions that are proposed to avoid such disasters in the future are: (i) Construction of the required flood protection structural works not only in the town, but also in the mountainous catchment area, and removal of all existing constructions that reduce the cross-sectional area of the streams. (ii) Updating of the design of the works taking into account the global weather change effects that may increase the design flow rates. (iii) Development of an Integrated Storm water Management Plan with Best Management Practices that combine the proposed structural works with non-structural measures. (iv) Development and implementation of an EWS at the level of the Prefecture of Attica that should be operated in small time steps of 5-10 minutes to be able to cope with fast flash floods. The proposed EWS consists of the observatory network for collecting environmental data that include rainfall and stream flow information, upon which to base warnings, and the IT infrastructure that allows for the collection and analysis of data, warning preparation, and communication channels for distributing warning and other information to constituents.
\end{abstract}

Keywords: Flash floods; Attica; storm protection works; Early warning systems; Hydrodynamic modeling; Hydrological modeling

Abbrevations: IFRC: International Federation of Red Cross; FFG: FF Guidance; WFOs: Weather Forecast Offices; NWS: National Weather Service; GPM: Global Precipitation Measurement; NOA: National Observatory of Athens; FEMA: Federal Emergency Management Agency; ISMP: Integrated Stormwater Management Plan

\section{Introduction}

A flash flood (FF) is defined as a flood that follows shortly, i.e. within a few hours, after a heavy or excessive rainfall event [1]. In the period $1950-2006,40 \%$ of the flood-related casualties in Europe are due to FF events that take place in different geographical scenarios [2]. In the Mediterranean region, FFs usually occur in spring and autumn, after intense, heavy and irregularly distributed rains [2].

The region of Attica is characterised by a relatively large number of floods over a long period of time; this fact is even mentioned in the Greek mythology, according to which the Ogygian flood in the $10^{\text {th }}$ millennium BCE is said to have covered the whole world and was so devastating that Attica remained without kings until the reign of Cecrops. Diakakis et al. [3] compiled the flooding phenomena during the period 1880-2010 in Greece and identified 545 events that caused 686 human casualties and inflicted extensive damage across the country; their results showed seasonality patterns with more events clustering in November and that the highest numbers of events and casualties occurred in Attica. The FF in Madra on the 15th of November 2017 verified the findings of Diakakis et al. [3]; it was the third most disastrous 'November' flood in Attica following the floods of Western suburbs of Athens in 1961 (43 deaths) and 1977 (37 deaths), which occurred 11 years after the 'warning flood' (2 deaths) in the same area in January 1996. According to the Emergency Plan of Action Operations Update [4] issued by the International Federation of Red Cross and Red Crescent Societies (IFRC) 'The majority of the population was affected by the floods. The most immediate impact is the loss of life. A total of 23 deaths have been reported, and 24 injured. Secondly, basements and ground floors of buildings in the city were also seriously impacted; officials estimated 80 per cent of the city area had been affected, except for some located on the hills'.

Up to now, there are no publications on the FFs in Mandra in scientific journals, but only announcements, bulletins and interviews in the press. The scope of the present work is to 


\section{Civil Engineering Research Journal}

answer a series of technical questions on the FF in Mandra and based on these answers to propose actions in order to avoid such a disaster in the future.

\section{The Flash Flood in Mandra}

The hydrographic network of the mountain Pateras consists of a number of converging creeks with steep slopes that form the two main streams (s.) crossing the town of Mandra that are s. Soures and s. Agia Aikaterini, whose catchment area is equal to 23.0 and $22.0 \mathrm{~km}^{2}$, respectively. These streams that are shown in
Figure 1 are characterized by significant morphological changes due to the intensive construction activities in the greater area that resulted in a dramatic decrease of their available crosssectional areas and the occurrence of floods even at low flow rates. The need to face the frequent flood problems in Mandra resulted in the beginning of the final study of the storm water works in July 2012; its environmental terms were approved in July 2014 and the boundaries of the two streams were specified in January 2016. The main components of these structural works, which are shown in Figure 1, are

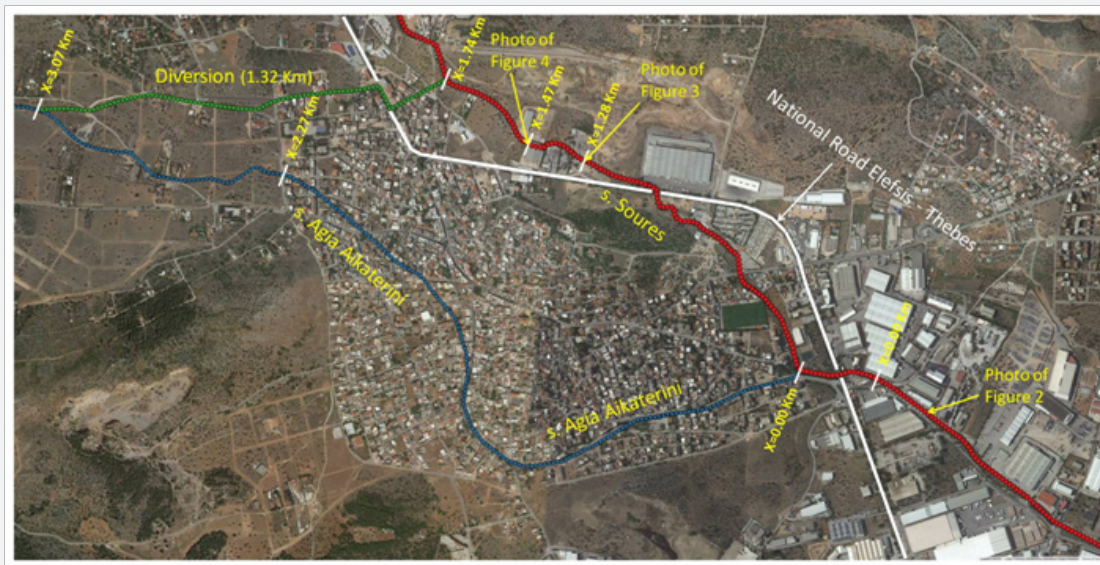

Figure 1: The main streams of Mandra and their technical works (based on Google Earth).

i. the regulation of $s$. Soures (length $=\mathrm{L}=1.74 \mathrm{~km}$, flow rate $=\mathrm{Q}=91-125 \mathrm{~m}^{3} / \mathrm{s}$ and cross-sectional area $=\mathrm{A}=24.0$ $34.4 \mathrm{~m}^{2}$ ), and

ii. The partial diversion of the s. Agia Aikaterini $(\mathrm{L}=1.52 \mathrm{~km}$, $\mathrm{Q}=47 \mathrm{~m}^{3} / \mathrm{s}$ and $\mathrm{A}=12.5-24.0 \mathrm{~m}^{2}$ ) to s. Soures. Downstream of its diversion location, the s. Agia Aikaterini continues to flow through the town of Mandra via an existing, enclosed rectangular conduit $\left(\mathrm{L}=2.27 \mathrm{~km}, \mathrm{Q}=10 \mathrm{~m}^{3} / \mathrm{s}\right.$ and $\left.\mathrm{A}=3.4 \mathrm{~m}^{2}\right)$ that is shown in Figure 2 until it meets s. Soures. Then, the latter ends up at the beginning of the existing, regulated part of the s. Soures that consists of a twin channel, each of dimensions $4.0 \times 3.0 \mathrm{~m}^{2}$, i.e. $\mathrm{A}=24.0 \mathrm{~m}^{2}$, which is shown in Figure 2 after the flood incident. The flow rates were determined for a return period equal to $\mathrm{T}=50$ years. Moreover, according to the flood risk management plans for Greece that were announced for public consultation in 2017 within the implementation of the Floods Directive 2007/60/EC [5], the region of Mandra belongs in one of the nine low zones of high flood risk in the Prefecture of Attica.

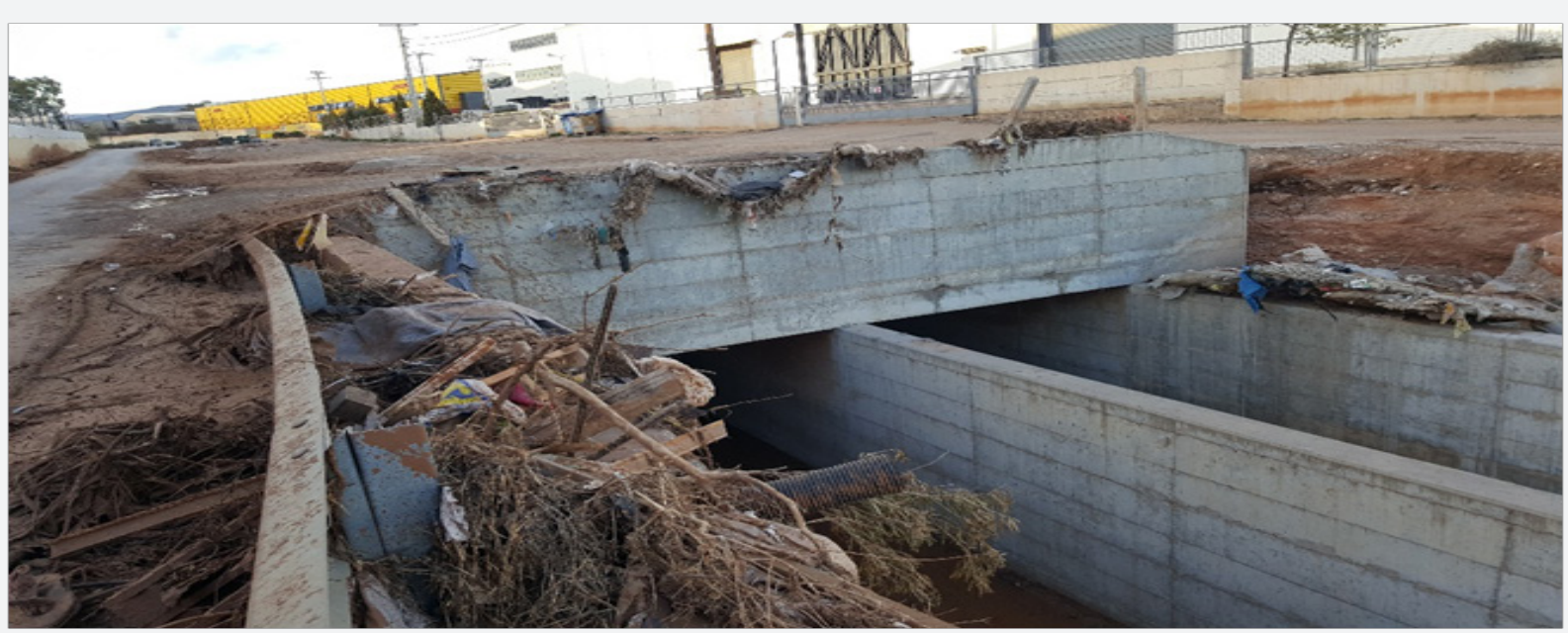

Figure 2: Photograph of the regulated part of the s. Soures after the flood. 


\section{Civil Engineering Research Journal}

\section{Lessons Learned}

The FF in Madra posed a series of technical questions that are presented below; the answers to these questions show clearly the lessons that we learned from this disaster and what actions we need to perform.

\section{What was the behaviour of the streams, the roads and the relevant technical works during the flood?}

The main characteristic of the streams is the significant reduction of their cross-sectional areas to extremely small values that practically tend to zero; i.e. in certain areas the streams practically vanished. It should be noted, that based on an investigation of the flood event [6], the General Inspector of Public Administration stated that 'bureaucracy and human factors played a crucial role in the tragedy', 'wrong evaluation of the priorities impeded the construction of the necessary flood protection works in the region' and 'responsibilities should also be sought in the past when various public infrastructure, such as the National Road Elefsis-Thebes, and private constructions were erected over the two major filled-in streams while the necessary water drainage pipes were either too small or they were not built at all' [7]. Indicatively, Figure $3 \& 4$ show the culverts of s. Soures at $\mathrm{x}=1.28 \mathrm{~km}$ (two pipes; $\mathrm{A} \sim 2.0 \mathrm{~m}^{2}$ ) and at $\mathrm{x}=1.47 \mathrm{~km}$ (two openings; $\mathrm{A} \sim 10.0 \mathrm{~m}^{2}$ ) under a building, respectively. Taking into account that

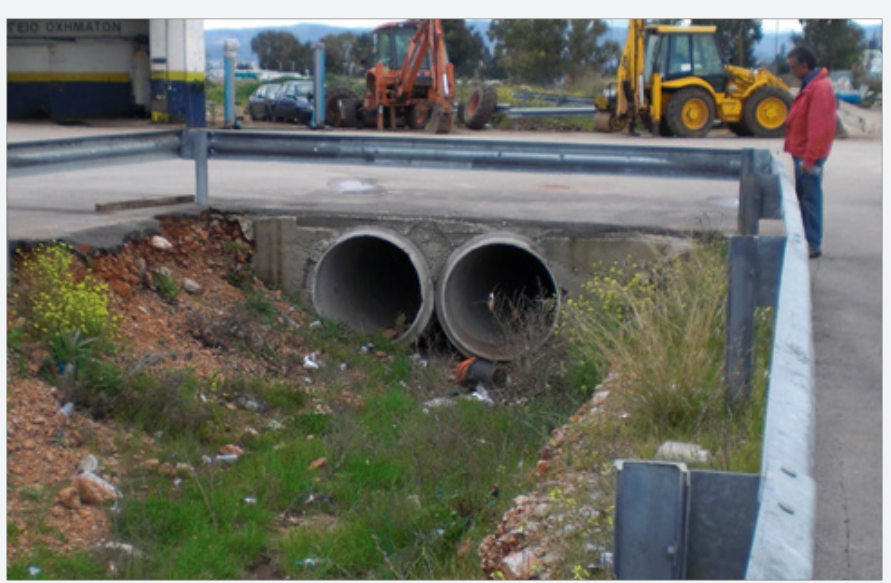

Figure 3: Photograph of a culvert of $\mathrm{s}$. Soures at $\mathrm{x}=1.28 \mathrm{~km}$.

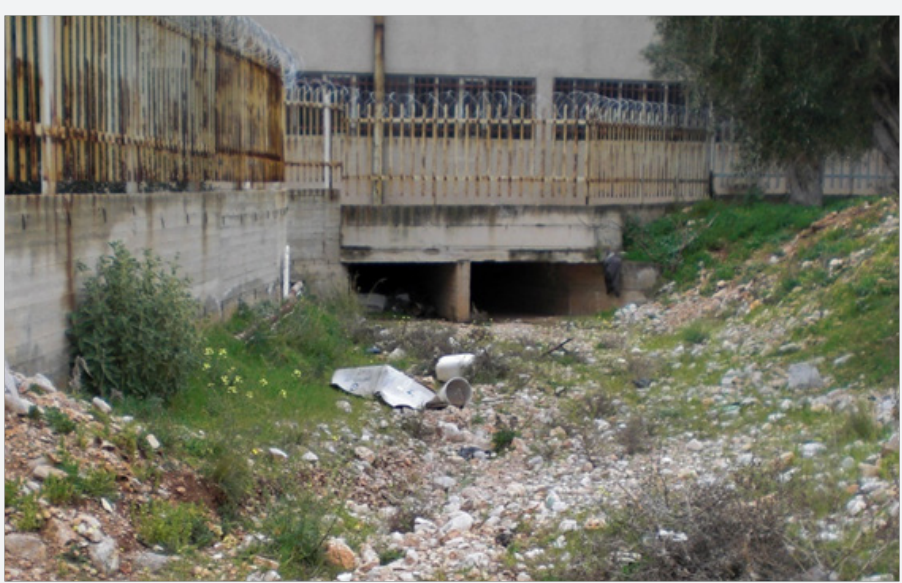

Figure 4: Photograph of a culvert of the $\mathrm{s}$. Soures (under a building) at $\mathrm{x}=1.47 \mathrm{~km}$.

i. the minimum required cross sectional area of the streams (without the diversion) varies between 20 and $40 \mathrm{~m}^{2}$,

ii. The s. Soures flows almost parallel to the National Road Elefsis-Thebes (Figure 1),

iii. The s. Agia Aikaterini passes through the town of Mandra under its main streets, it was expected that during the flood the streams of Soures and Agia Aikaterini were replaced by the roads of Mandra. Moreover, due to very high flow velocities (in certain areas the terrain was very steep) and bottom shear stresses, the flood caused significant soil erosion and carried away not only large quantities of solids (practically it was a mud-flow), but also extremely large and heavy objects, such as buses and cars. Without ignoring possible downstream or debris effects on the flow behavior, the traces of the mud-flow on the wall on the left side of the photograph of Figure 2 verify the description of the IFRC [4] 
'Watermarks were visible at anywhere from 1.0 to $2.5 \mathrm{~m}$ in height' and clearly show that even the cross-sectional area of $24.0 \mathrm{~m}^{2}$ of the regulated part of the s. Soures was not sufficient to carry the flood.

\section{Was there an early warning system or flash flood guid- ance in mandra?}

There are various EWSs worldwide; for example, in the USA the National Weather Service (NWS) and its local Weather Forecast Offices (WFOs) issue FF warnings and watches. A FF watch means that flooding is possible and those affected need to prepare to evacuate, while a FF warning means that flooding is occurring or about to occur and those in the affected area should go to higher ground immediately because FF can take only a few minutes to develop. The delivery of warning or watch is based on the comparison of FF guidance (FFG) values with actual rainfall amounts [8]. FFG is the amount of rainfall required over a given area during a given duration to cause small streams to flood; its estimation is based on the real time soil moisture that is typically calculated by operational soil moisture models and stream flow conditions that are determined by hydrodynamic models for the area [9]. In Greece there are no EWSs for FFs or FFGs.

\section{Could we have predicted the actual rainfall amount in Mandra? Was it higher than an estimated FFG in the region?}

We can estimate the rainfall amount via meteorological models, determine it with meteorological radars and verify it with rain gauge measurements. According to the Press Bulletin of the National Observatory of Athens (NOA) [10] on the $20^{\text {th }}$ of
November, the transportable polarimetric weather radar XPol of the Institute for Environmental Research and Sustainable Development measured on the 15th of November a zone of very intensive rainfall over the greater area of Mandra of a total height higher than $200 \mathrm{~mm}$ in 6 hours (Figure 5). Furthermore, scientists of the University of Athens announced that the Poseidon Weather Forecast System of the Hellenic Centre for Marine Research [11] 'has shown 48 hours before the storm that in the mountain Pateras more than $50 \mathrm{~mm}$ of rainfall was expected'. Moreover, scientists of the University of Athens used satellite images of the NASA Global Precipitation Measurement (GPM) Integrated Multi-satellitE Retrievals for GPM [12] to estimate that 'the region upstream of Mandra received within 7 hours a height of rainfall higher than $150 \mathrm{~mm}$ that corresponds to $40 \%$ of the total annual rainfall in the region'. All the abovementioned estimations were announced in the mass media after the flood. The measurement of the radar of the NOA and the weather forecast of Poseidon could possibly have been used to predict the actual rainfall; the Citizen Protection Ministry and the General Secretariat for Civil Protection expressed a different opinion claiming that that there was no reliable rainfall forecast [13]. Regarding the estimation of the FFG in Mandra, it is very difficult to make even an approximation, since the FFG depends strongly on local conditions; for example, local FFs in Poland are usually triggered by rainfall lasting up to two hours with the mean rainfall intensity ranging from $20-80 \mathrm{~mm} / \mathrm{h}$, i.e. an expected FFG value would be around $20 \mathrm{~mm} / \mathrm{h}$ [14]. Nevertheless, a total rainfall around $200 \mathrm{~mm}$ in 6 hours can be considered as a value that is well above any expected FFG in any region and certainly would have triggered a warning of an operating EWS.

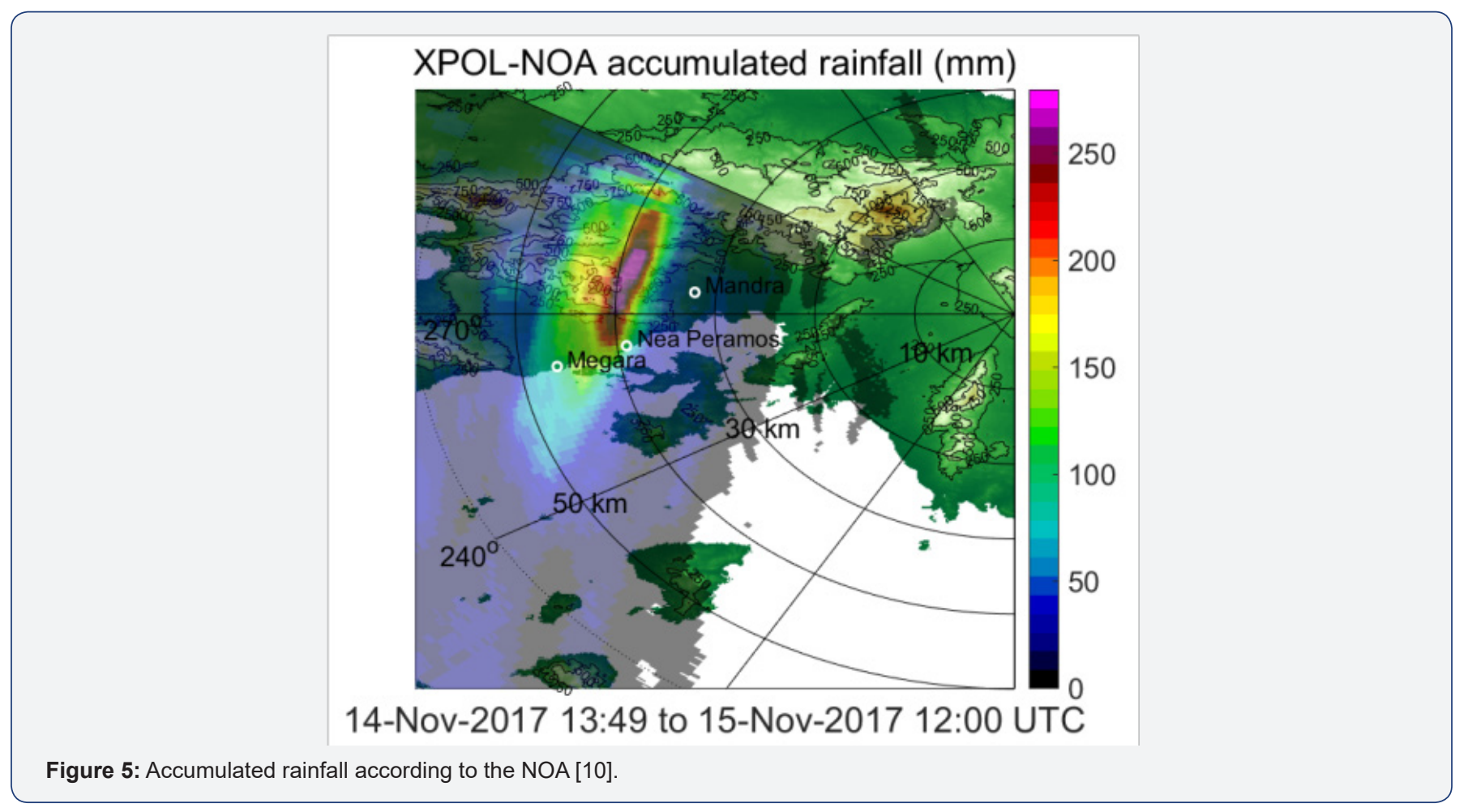


Could we have measured the actual rainfall amount in the catchment area or the water elevation in the two streams?

No, because there are no rain gauges in the catchment area (practically, to verify the measurement of the radar) and no water level sensors in the two streams. Moreover, according to NOA the rainfall heights in the neighboring meteorological stations of Elefsis, Vilia and Agioi Theodoroi were measured equal to $35 \mathrm{~mm}, 35 \mathrm{~mm}$ and $22 \mathrm{~mm}$, respectively; in other words, the FF in Mandra was a very local event, like the majority of FFs worldwide.

\section{Would the presence of the structural works have re- duced the effects of flood?}

Based on preliminary estimations, the peak values of the hydrographs at the upstream ends of the two streams were higher than $220 \mathrm{~m}^{3} / \mathrm{s}$ and correspond to $\mathrm{T}=150-200$ years or even higher. These values correspond to maximum unit discharges around $10 \mathrm{~m}^{3} / \mathrm{s} \mathrm{km}^{2}$, while theoretically they may reach values up to 16-26 [2] or even $28 \mathrm{~m}^{3} / \mathrm{s} \mathrm{km}^{2}$ [15], i.e. the peak flow rates may be up to about $600 \mathrm{~m}^{3} / \mathrm{s}$, which are more than 4-times and twice higher than the hydraulic capacity of the s. Agia Aikaterini and $s$. Soures, respectively. In any case, the presence of the structural works would have certainly reduced the inundation area, provided that there were no other constructions in the streams that reduced their cross-sectional area.

\section{Could we have avoided the disaster, if an EWS was in operation linked with a preparedness plan?}

According to the Federal Emergency Management Agency (FEMA) "Seconds May Matter in Flash Flood Warning" [16]. Therefore, the answer to this question is certainly positive, even the EWS is not a perfect one. A warning by the EWS a few minutes before the arrival of the flood wave of the s. Agia Aikaterini in the town would probably have permitted the people to perform the most important first step of the simplest preparedness plan 'Move quickly to higher ground. Save yourself, not your belongings. The most important thing is your safety' [17]. Moreover, it would have allowed the closing of the National Road Elefsis-Thebes at its entrance in the south-eastern part of the town, which would have possibly reduced the largest number of victims that was observed in the upstream northern part of the National Road [6] that replaced s. Soures during flood passage.

\section{Discussion: What needs to be Done?}

The answers to the above-mentioned questions show clearly the actions that we should perform to avoid the occurrence of similar events in the future, which are briefly the following:

a. Construction of the required flood protection structural works not only in the town, but also in the mountainous area; all existing constructions that reduce the cross-sectional area of the streams should be removed. Furthermore, it is suggested to update the design of the works taking into account the global weather change effects that may increase the design flow rates. An Integrated Stormwater Management Plan (ISMP) could also be developed using an ecosystembased approach, which includes Best Management Practices combining the proposed structural works with nonstructural measures; its goal is to balance flood and erosion protection, storm water engineering, land use planning and environmental (mainly water quality) protection.

b. Development and implementation of an EWS that can be applied at the level of the Prefecture of Attica, which includes the town of Mandra. The main components of such an EWS that is shown in Figure 6 are

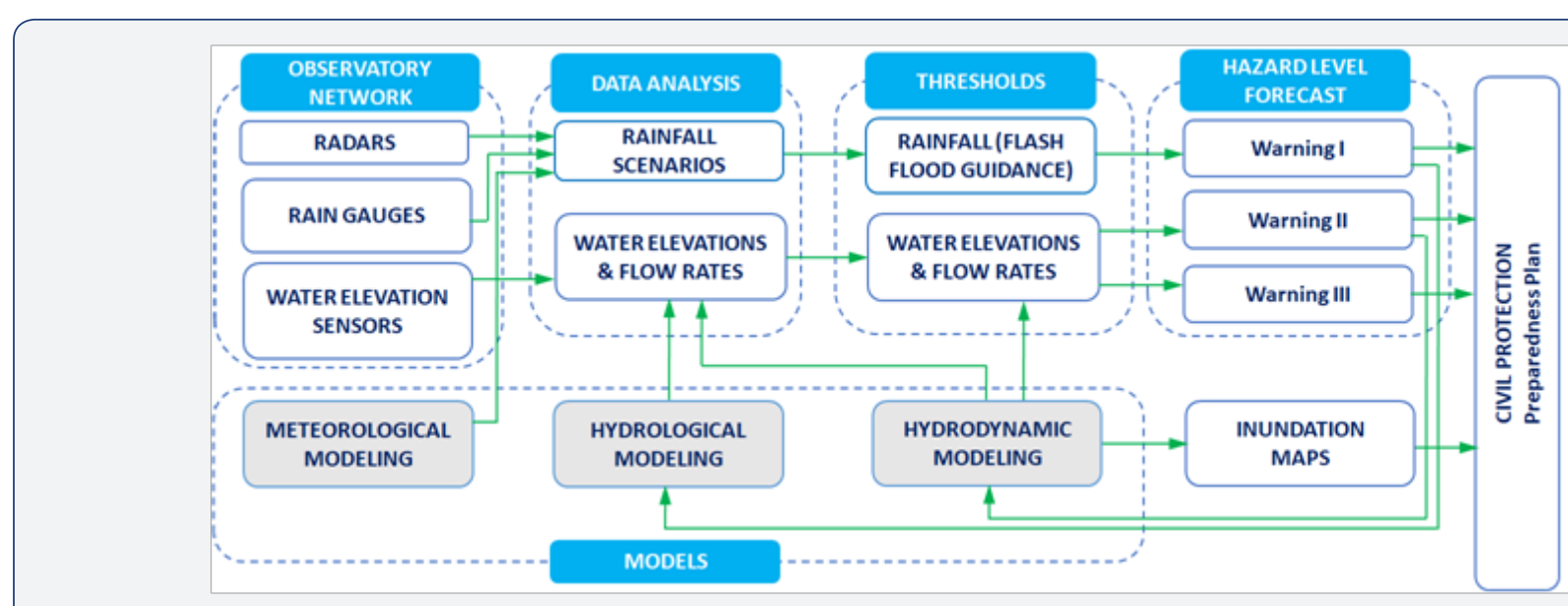

Figure 6: The proposed end-to-end EWS.

i. the observatory network for collecting environmental data that include rainfall and stream flow information, upon which to base warnings, and

ii. the IT infrastructure that allows for the collection and analysis of network data, warning preparation, and communication channels for distributing warning and other information to constituents [18].

The EWS should be operated in small time steps of 5-10 minutes to be able to cope with fast FFs. Every time step, rainfall data from the radars are collected and compared with 
predictions of meteorological models; then, a precipitation analysis - forecast is performed by nowcasting methods to produce rainfall scenarios that allow their direct comparison with rainfall thresholds, for example FFG values. In case the rainfall threshold is exceeded, the first level of 'warning' is issued and hydrological modeling calculations are performed for all rainfall scenarios to determine the corresponding runoff and flow rates. These flow rates are compared with discharge thresholds, for example flow-rates for $\mathrm{T}=5$ years; in case these thresholds are exceeded, the second and most important level of 'warning' is issued. For FF of relatively long lead times ( $>40$ minutes), hydrodynamic modeling calculations can be performed for all scenarios to determine the flow rates and the water levels at specific locations of the streams and compare them with corresponding thresholds; when thresholds are exceeded the third level of 'warning' is issued. The threshold values for water elevations and flow rates are calculated via hydrodynamic models that are also used to determine the inundation regions that are embedded in the preparedness plans, which should also be in place. Finally, the population should be aware of the FF hazard and be prepared to take appropriate actions when a warning is received.

\section{References}

1. Georgakakos KP (1986) On the design of national, real-time warning systems with capability for site-specific, flash-flood forecasts. Bulletin of the American Meteorological Society 67(10): 1233-1239.

2. Gaume E, Bain V, Bernardara P, Newinger O, Barbuc M, Bateman A, et al. (2009) A compilation of data on European flash floods. J. Hydrol. 367(1-2): 70-78.

3. Diakakis M, Mavroulis S, Deligiannakis G (2012) Floods in Greece, a statistical and spatial approach. Natural Hazards 62(2): 485-500.
4. (2017) Greece: Floods Emergency Plan of Action (EPoA) DREF n ${ }^{\circ}$ MDRGR002

5. European Union (2007) Directive 2007/60/EC of the European Parliament and of the Council of 23 October 2007 on the assessment and management of flood risks-Official Journal of the European Union, L 288/27111.

6. http://s.kathimerini.gr/resources/article-files/mandra_porisma.pdf (in Greek).

7. GCT Team (2017) Local authorities and bureaucracy blamed for Mandra floods.

8. Carpenter TM, Sperfslage JA, Georgakakos KP, Sweeney T, Fread DL (1999) National threshold runoff estimation utilizing GIS in support of operational flash flood warning systems. J Hydrol 224(1-2): 21-44.

9. Ohio RFC (2018) Flash Flood Guidance. River Forecast Center.

10. http://www.noa.gr/index.php?option=com_content\&view=article\&id=1074\&catid=86\&Itemid=547\&lang=el (in Greek).

11. (2018) Monitoring, Forecasting and information system for the Greek Seas.

12. Huffman GJ, Bolvin DT, Braithwaite D, Hsu K, et al. (2018) GPM Integrated Multi-Satellite Retrievals for GPM (IMERG) Algorithm Theoretical Basis Document (ATBD) v5.2.

13. (2017) There was no reliable description on Mandra floods.

14. Bryndal T (2015) Local flash floods in Central Europe: A case study of Poland, Norsk Geografisk Tidsskrift - Norwegian Journal of Geography 69(5): 288-298.

15. Viessman W Jr, Lewis GL, Knapp JW (1989) Introduction to Hydrology, $3^{\text {rd }}$ edition, Happer \& Row, New York, USA.

16. (2008) Seconds May Matter in Flash Flood Warning.

17. (1999) Flood and Flash Flood.

18. Examples of End-to-End Flash Flood Early Warning Systems (EWS). Chapter 8.

\section{Your next submission with Juniper Publishers will reach you the below assets}

- Quality Editorial service

- Swift Peer Review

- Reprints availability

- E-prints Service

- Manuscript Podcast for convenient understanding

- Global attainment for your research

- Manuscript accessibility in different formats

( Pdf, E-pub, Full Text, Audio)

- Unceasing customer service

Track the below URL for one-step submission https://juniperpublishers.com/online-submission.php 